\title{
Przeciwko Austrii jako pocztówce Wokół książki Moniki Muskały Między „Placem Bohaterów” a „Rechnitz” Austriackie rozliczenia
}

Książka Moniki Muskały, wielokrotnie nagradzanej tłumaczki utworów między innymi Thomasa Bernharda, Wernera Schwaba, Friedricha Schillera, Gerharda Rotha, Heinera Müllera czy Franka Wedekinda, dramatopisarki ${ }^{1}$, która czasami sięga po formę filmową ${ }^{2}$, ale też od dawna uważnej komentatorki oraz interpretatorki niemieckojęzycznej rzeczywistości artystyczno-literackiej i społecznej, rozpoczyna się słowami: „Dla Jolandy”, i, jak czytamy dalej, powstała „w domu, który kiedyś był jej domem”3. Na rewersie strony z dedykacją autorka przytacza fragment jednego z donosów, jakie słał do gestapo dr Friedrich

${ }^{1}$ Trzy sztuki, które autorka napisała pod pseudonimem Amanita Muskaria wraz ze swoją siostrą Gabrielą Muskałą, to: Podróż do Buenos Aires. Work in Regress (2001), Daily Soup (2007) i Cicha noc (2016). Wspólnie z Januszem Margańskim powstało natomiast libretto musicalu $W$ pogoni za bajka (2011). Tak w wywiadzie dla portalu ZAiKS.TEATR Muskała mówiła o sztukach tworzonych wraz z siostrą: „Piszemy zawsze o pamięci, a raczej niepamięci” („Bez formy rzeczywistość jest amebą. Z M. MusKa£Ą rozmawia J. BieRnACKA. „ZAiKS.TEATR” 2017, nr 12. Dostępne w Internecie: http://www.zaiksteatr.pl/rozmowaz.id_502,monika_muskala [data dostępu: 24.07.2019]).

${ }^{2}$ Monika Muskała jest współautorką scenariusza krótkometrażowego filmu Pasja według polskiej społeczności miasteczka Pruchnik (2009) w reżyserii męża tłumaczki, Andreasa Horvatha, z którym współpracowała także podczas realizacji filmów $Z$ punktu widzenia emerytowanego portiera (2006) oraz Zauroczenie (2010). W albumach fotograficznych Horvatha - Jakutien (2003) i Heartlands (2007) - znajdują się natomiast eseje Muskały.

${ }^{3}$ M. Muska£a: Między „Placem Bohaterów” a „Rechnitz”. Austriackie rozliczenia. Kraków 2016, s. 7. Przy kolejnych przytoczeniach fragmentów tej książki numery stron podaję w nawiasie, bezpośrednio po cytacie. 
Hoch, sąsiad żydowskiego małżeństwa Jolandy i Eduarda Biglerów, a na kolejnej, także nienumerowanej, krótką historię ich życia. W dalszych częściach tego obszernego tomu składającego się z krótkich esejów, rozmów i fotografii mieści się jeszcze wiele śladów żydowskich historii, choć są nimi przeważnie narracje literackie. Do rzeczywistych losów żydowskich Muskała powraca tuż przed zamykającym publikację utworem Elfriede Jelinek z 2008 roku pt. Rechnitz $(\text { Anioł Zagłady) })^{4}$, wspominając wydarzenia, do jakich twórczo nawiązuje dramat austriackiej pisarki.

Omawiany zbiór tekstów i obrazów ukazał się w wydawnictwie Korporacja Ha!art, w serii Linia Teatralna ${ }^{5}$ podejmującej „dyskusję o najnowszej kulturze”, gdzie „wciąż brakuje wnikliwych i interdyscyplinarnych opisów zjawisk, które na trwałe zmieniły oblicze współczesnego teatru" - a w przypadku zdarzeń opisywanych przez Muskałę: także współczesnej rzeczywistości kulturowej i społeczno-politycznej.

Tytułowy obszar pomiędzy wiedeńskim Heldenplatz a Rechnitz to niewielka część, wschodni i północno-wschodni bok Austrii. Daleko stąd do Linzu, który Hitler nazywał swoim ukochanym miastem i któremu podarował posąg Afrodyty, do Wels, gdzie mieściło się gimnazjum silnie propagujące idee „Wielkiej Rzeszy" (Großreich) i narodowego socjalizmu, do Salzburga czy Mauthausen. Bliżej, choć nadal poza linią Wiedeń - Rechnitz, leży też Graz, w okolicach którego w czasie pierwszej wojny światowej działał obóz Thalerhof ${ }^{6}$. Obszar, który wyznacza tytuł książki Muskały, nie ma charakteru geograficznego, lecz tematyczny (rozliczeniowy). Na tej linii dzieje się coś z pamięcią i austriackim imaginarium dotyczącym czasu od Anschlussu do ostatnich tygodni wojny.

Kompozycja tomu mieszkającej od wielu lat w Austrii Moniki Muskały połączenie historii prywatnej, wydarzeń społeczno-politycznych i literatury oddaje specyfikę austriackiej próby rozliczania się z przeszłością, odmiennej od niemieckiego Historikerstreit ${ }^{7}$. Publiczna debata dotycząca roli narodowego socjalizmu w historii Niemiec narodziła się w połowie lat $80 . \mathrm{z}$ akademickiego

${ }^{4}$ Pierwodruk tłumaczenia fragmentów tego utworu Jelinek zob. w: „Notatnik Teatralny” 2012/2013, nr 70/71, s. 316-320.

${ }^{5}$ Linia Teatralna przygotowywana jest pod redakcją Igi Gańczarczyk. Do tej pory w serii tej ukazało się 19 publikacji książkowych, m.in. Strategie obrazów. Oko historii 1 Georges’a Didi-Hubermana (2011) czy Przeciw Gesamtkunstwerk Heinera Goebbelsa (2015). Zob. http://ha.art.pl/ wydawnictwo/linie-wydawnicze/1078-linia-teatralna [data dostępu: 24.07.2019].

${ }^{6}$ W czasie pierwszej wojny światowej działał tam austriacko-węgierski obóz dla internowanych.

7 Zob. J. Holzer w: Historikerstreit. Spór o miejsce III Rzeszy w historii Niemiec. [Red. M. ŁuKAsIEwICZ]. Londyn 1990; Nazizm, Trzecia Rzesza a procesy modernizacji. Wybór i oprac. H. ORŁowski. Poznań 2000; O kondycji Niemiec. Tożsamość niemiecka $w$ debatach intelektualistów po 1945 roku. Red. J. JabŁkowska, L. Żyliński. Poznań 2008; M. Materniak-PawŁowska, H. Olszewski: Spory o narodowy socjalizm na łamach Poznańskiej Biblioteki Niemieckiej. „Czasopismo Prawno-Historyczne" 2014, T. 66, z. 1, s. 323-336. 
sporu historyków ${ }^{8}$, choć jego znacząca część publikowana była w periodykach i książkach broszurowych dostępnych szerokiej, nieakademickiej publicznoś$\mathrm{ci}^{9}$. Spór ten został wywołany przez próbę relatywizowania niemieckiej winy i chociaż zakończył się obaleniem mitów oraz stereotypów powtarzanych przez historyków skrajnej prawicy, to mocne głosy strony przeciwnej nie były jednoznaczne z odpowiedzią na wszystkie niewygodne pytania o przeszłość Niemiec. Wiele tematów - zwłaszcza tych związanych z postawami społecznymi w czasie wojny oraz z późniejszym, silnie tkwiącym w myśleniu i zachowaniu, powojennym zapleczem narodowosocjalistycznym - wyraźniej wybrzmiało w literaturze rozliczeniowej, zwłaszcza austriackiej. Tamtejsze mierzenie się z przeszłością (i ówczesną teraźniejszością lat 80.) miało formę rewolty, która wywróciła przekonanie o Austrii jako „pierwszej ofierze Hitlera”, rewolty bez przygotowania, jakim w debacie niemieckiej były jej pierwsze, prawicowe głosy osłabiające niemieckość zbrodni, rewolty z gruntu przynależnej teatrowi i językom tak silnym, jak twórczość autorów będących bohaterami książki Muskały.

Tom skomponowany jest w sposób niezwykle precyzyjny, zarówno pod względem doboru oraz kolejności tekstów, jak i przeplatających je fotografii oraz wyróżnionych cytatów. Po przywołanym już fragmencie dotyczącym Jolandy, swoistym liście do czytelnika, zamieszczony jest esej Janusza Margańskiego Ekskurs $i$ dyskurs (zamiast wstępu), główną część książki otwiera natomiast zdjęcie z 15 marca 1938 roku, przedstawiające Burgtheater, a przed nim kolumnę samochodów z Hitlerem na czele, zmierzającą w stronę Heldenplatz. Dalej autorka zarysowuje powojenną atmosferę milczenia i prób wymazania przeszłości, przedstawia kolejne figury ówczesnego zapomnienia: między innymi Kurta Waldheima, który „zapomniał” o pięćdziesięciu tysiącach Żydów deportowanych z Salonik do Auschwitz, Heinricha Grossa, odpowiedzialnego za nazistowskie pseudonaukowe eksperymenty medyczne, czy skrajnie prawicowego Jörga Haidera. Następny fragment książki składa się z komentarza Szymona Wiesenthala do sześćdziesiątej rocznicy Anschlussu i spóźnionych rozliczeń oraz z dwóch pytań z 1998 roku do Gerharda Rotha. Wybebeszanie (tytuł kolejnego rozdziału)

${ }^{8}$ O określeniu tym Stanisław Żerko pisze, że było „dalekie od precyzji, gdyż tylko część uczestników stanowili historycy. Także oskarżenia, jakie padały w trakcie dyskusji, miały niewiele wspólnego z uczciwością naukowego sporu. Niemniej wypadnie przyznać rację Hermanowi Glaserowi, który w wydanej z okazji czterdziestolecia Republiki Federalnej Niemiec trzytomowej syntezie historii kultury RFN podkreślił, że Historikerstreit swym zasięgiem przewyższał wszystkie dotychczas prowadzone w Niemczech Zachodnich dyskusje. Zresztą również w dziejach zjednoczonych Niemiec sporu na tak wielką skalę, tak bardzo upolitycznionego i naładowanego tak silnymi emocjami nie było" (S. ŻERKo: Ernst Nolte, główna postać niemieckiego „sporu historyków”. „Biuletyn Instytutu Zachodniego” 2016, nr 267. Dostępne w Internecie: https:// iz.poznan.pl/plik,pobierz,1644,b76a1391a109eelc17fa0e0f87d379ec/267Noltesporhistorykow.pdf [data dostępu: 24.07.2019]).

${ }^{9}$ H. OrŁowski: Nazizm, Trzecia Rzesza a procesy modernizacji. „Przegląd Zachodni” 1992, nr 4 , s. 81 . 
to natomiast mechanizm przeciwny do milczącego ukrywania i jeden z głównych rodzajów ekspresji austriackich akcjonistów (między innymi Hermanna Nitscha). Słowo to zahacza też o specyfikę filmów Ulricha Seidla czy - mniej dosłownie - Michaela Hanekego oraz samej literatury austriackiej, która „,istnieje, odkąd zaczęła się zastanawiać nad własną tożsamością" (s. 40). Esej ten jest wprowadzeniem do rozdziałów (to zarówno wywiady, jak i teksty Moniki Muskały) poświęconych takim twórcom, jak: Thomas Bernhard, Gerhard Roth, Peter Turrini, Werner Schwab, Felix Mitterer, Peter Handke, Urlich Seidl i Elfriede Jelinek. Nie sposób nie zauważyć, że część o twórczości Bernharda (w tym rozmowa $\mathrm{z}$ Hermannem Beilem ${ }^{10}$ oraz rozdział $\mathrm{w}$ całości dotyczący Wymazywania...) jest najobszerniejsza, co oddaje jej znaczenie dla rozliczeniowej (i nie tylko) literatury tego obszaru ${ }^{11}$.

Austriackie rozliczenia rozpoczęła gwałtownie dopiero (nie bez znaczenia jest, że słowo to pojawia się w książce Muskały nader często) afera Waldheima z 1986 roku, który pominął w swoim życiorysie niewygodne - zwłaszcza w czasie kampanii prezydenckiej - lata wojny. W tym samym roku ukazała się też powieść-testament Bernharda Wymazywanie. Rozpad, ale nieporównywalnie większy oddźwięk społeczny miała teatralna premiera Heldenplatz ${ }^{12}$ w roku 1988, nazywanym Bedenkjahr („rokiem refleksji”). Sztuka Bernharda, zanim jeszcze rozegrała się na deskach Burgtheater, zadziałała na poziomie pogłosek i wyrwanych z całości zdań, do tego we wzburzonej atmosferze politycznej. Jak pisze Muskała:

Bezprecedensowe, zakrawające na histerię rozemocjonowanie całego narodu związane z przedstawieniem teatralnym i wściekłe spory toczone również przez ludzi, którzy do teatru nigdy nie chodzili, były echem niewybrzmiałej

${ }^{10}$ Beil wspomina m.in. głośny skandal dotyczący światła, który wydarzył się podczas prapremiery Ignoranta i szaleńca. Dyrekcja festiwalu w Salzburgu, mimo wcześniejszych obietnic, nie dopuściła wtedy do zgaszenia lampek bezpieczeństwa - Bernhard chciał, aby przez chwilę w sali zapanowała całkowita ciemność. Zdarzenie to w przewrotny sposób przypomniało o sobie 17 lutego 2018 r. przed spektaklem na podstawie Heldenplatz Bernharda, w reżyserii Grzegorza Wiśniewskiego - z powodu awarii prądu tuż przed planowanym rozpoczęciem przedstawienia zgasło oświetlenie, a kurtyna zatrzymała się niewiele ponad podłogą. O podobnym Bernhardowym psikusie pisze Adam Lipszyc na końcu swojej recenzji.

${ }^{11}$ Przykładowo, Gerhard Roth w wywiadzie z Muskałą mówi: „Dopiero wraz z Bernhardem doszła znowu do głosu krytyczna postawa wobec kraju, wobec państwa. Zaczęli przejawiać ją także inni pisarze" (s. 144).

${ }^{12}$ Sztuka ta rozpoczyna się w mieszkaniu zmarłego niedawno żydowskiego intelektualisty, który wyjechał z Wiednia po dojściu do władzy narodowych socjalistów. Pięćdziesiąt lat później rodzina Schusterów powraca do mieszkania, którego okna wychodzą na plac Bohaterów, ale okazuje się, że austriackie społeczeństwo nie zdążyło rozliczyć się z przeszłością, a antysemityzm jeszcze się nasilił - z Heldenplatz wciąż dochodzi echo odgłosów wiwatującego na cześć Hitlera tłumu. Profesor Schuster postanawia wrócić do Oksfordu, ale tuż przed wyjazdem popełnia samobójstwo. 
jeszcze afery Waldheima, afery wciąż aktualnej, ponieważ jej wątpliwy bohater w 1988 roku nadal był prezydentem Austrii. Jak się okazało, spora część społeczeństwa miała poglądy nazistowskie i odznaczała się całkowitym brakiem refleksji na temat historycznej winy i odpowiedzialności za zbrodnie.

Rozliczenia dotyczyły więc nie tylko milczenia, stabilnego stanu zbiorowej amnezji, ale też „pozostałości ideologii nazistowskiej w ludzkich umysłach”, jak mówił w rozmowie z Muskałą Gerhard Roth na przełomie 1995 i 1996 roku. Debatę o austriackim uwikłaniu w nazizm podtrzymywała literatura, „z jej krytycyzmem i samokrytycyzmem, polemicznością i satyrycznością" ${ }^{\prime 3}$. Parafrazując słowa Zygmunta Hübnera o teatrze, można by powiedzieć: literatura, która się wtrąca ${ }^{14}$.

W tytułowym Rechnitz - austriackiej wiosce przy granicy węgierskiej podczas przyjęcia na zamku hrabiny Margit von Batthyány (z domu Thyssen-Bornemisza) doszło do masakry co najmniej stu osiemdziesięciu żydowskich robotników przymusowych ${ }^{15}$. Było to tuż przed Niedzielą Palmową, w nocy z 24 na 25 marca 1945 roku, i tuż przed wkroczeniem Armii Czerwonej, która

${ }^{13}$ Słowa Hermanna Beila. Por. M. MuskaŁa: Między „Placem Bohaterów” a „Rechnitz”..., s. 82 .

14 Zdanie to jest mottem Teatru Powszechnego w Warszawie. Tak mówił w rozmowie dla „Dwutygodnika” reżyser i dyrektor teatru Paweł Łysak: „Chcielibyśmy robić teatr wrażliwy na współczesność. Inicjujący albo zabierający głos w debacie publicznej. Teatr, który się nie zamyka, stawia trudne pytania, czegoś poszukuje. Bliska nam jest maksyma Zygmunta Hübnera - teatru, który się wtrąca" (Teatr, który się wtrąca. Rozmowa z Pawłem Łysakiem i Pawłem SzTARBowsкiм. „Dwutygodnik” 2014, nr 127. Dostępne w Internecie: https://www.dwutygodnik.com/ artykul/5059-teatr-ktory-sie-wtraca.html [data dostępu: 24.07.2019]).

15 „8 listopada 1944 r. rozpoczęły się Marsze Śmierci budapesztańskich Żydów do Hegyeshalom/Straß-Sommerein. Tam węgiersko-żydowscy robotnicy przymusowi rozdzieleni zostali do poszczególnych sekcji budowy południowo-wschodniego wału obronnego, przy czym w Köszeg wzniesione zostały dwa obozy. 24 marca 1945 przetransportowanych zostało około 1000 węgierskich Żydów z Köszeg przez Rechnitz do odcinka budowy w Burg. Dwustu z nich sklasyfikowano jako niezdolnych do pracy i przeniesiono do Rechnitz, na dworzec kolejowy, a stamtąd do Kreuzstadl. Tego samego wieczoru w zamku Batthyánych w Rechnitz odbyło się święto [przyjęcie/ bal na zamku w Rechnitz określane jest najczęściej słowem das Fest, tak jak przy akcji „Dożynki”, Aktion Erntefest - K.S.] lokalnych przywódców partii nazistowskiej, w którym uczestniczyło ok. 40-50 osób. Podczas przyjęcia Podezin zorganizował oddział egzekucyjny (Erschießungskommando) złożony z 14-15 osób z kręgu gości i przydzielił im broń potrzebną do »zlikwidowania« Żydów przetrzymywanych w Kreuzstadl. Po masowym morderstwie sprawcy wrócili do reszty gości. Grupa 30-40 innych żydowskich robotników przymusowych musiała pochować ciała. Następnego wieczoru robotnicy ci, Zuschauflerkommando, zostali rozstrzelani w pobliżu rzeźni” (tłum. - K.S.; http://www.kreuzstadl.net/index_long.html [data dostępu: 24.07.2019]). Na temat znaczenia słów Fest, Feier i Party w kontekście mówienia o masakrze Żydów w Rechnitz oraz powiązania tych określeń z okrucieństwem ostatniej fazy wojny zob. G. MERTz: Ein Massaker als Partyvergnügen. Der Diskurs zum Fall Rechnitz. In: Der Fall Rechnitz Das Massaker an Juden im März 1945. Mit einem Text von Elfriede Jelinek. Hrsg. W. Manoscheк. Wien 2009, s. 245-263. 
znajdowała się wtedy w odległości około pięciu kilometrów od Rechnitz. Zaproszonym notablom $\mathrm{z}$ miejscowego gestapo i SS towarzyszyło poczucie, że po raz ostatni mają w rękach władzę nad życiem i śmiercią. Po tym morderczym balu hrabina przeprowadziła się do Szwajcarii, gdzie hodowała konie i zajmowała się sztuką, a do Austrii przyjeżdżała na polowania. Jej kochanek Oldenburg ukrył się w Argentynie, a szef miejscowej NSDAP Franz Podezin, który rozdał około piętnastu uczestnikom wieczoru broń i wysłał ich do Kreuzstadl, gdzie przebywali Żydzi, „aż do 1963 roku mieszkał w Kilonii jako nierzucający się w oczy agent ubezpieczeniowy" (s. 326), a później uciekł do RPA i pracował w Johannesburgu, w firmie związanej z Thyssen-Krupp. Po zamku właściwie nie ma dziś śladów - spłonął podpalony prawdopodobnie przez nazistów, którzy chcieli uniknąć odpowiedzialności za masakrę węgierskich Żydów. Brakuje też głosów tych, którzy pamiętają tamtą tragiczną noc w Rechnitz - podczas śledztwa w 1946 roku zamordowano bowiem dwóch głównych świadków, a pozostali być może powodowani strachem - nie chcą mówić o przeszłości. Inną przyczyną milczenia jest wsparcie finansowe, jakiego hrabina Batthyány udzielała Rechnitz aż do lat 80., praktycznie do samej śmierci; David R.L. Litchfield pisze, że zamek był „sercem i duszą Rechnitz”'16.

Nadal nie odnaleziono więc masowego grobu, nad którym „zawisło milczenie"17 , choć podejmowano wiele prób. Nad lokalną pamięcią o Rechnitz czuwa jednak między innymi Paul Gulda, austriacki kompozytor i pianista o żydowskich korzeniach, urodzony w 1961 roku w Wiedniu jako syn Paoli Loew, aktorki Volkstheater i Burgtheater, oraz pianisty Friedricha Guldy. Paul Gulda angażuje się nie tylko w działalność artystyczną, pedagogiczną, ale i społeczną. Kilkukrotnie przygotowywał koncerty (i brał w nich udział) łączące muzykę z literaturą, między innymi z tekstami Heinricha Heinego, Hermanna Hessego, Ingeborg Bachmann, Bertolta Brechta. Z okazji pięćdziesiątej czwartej rocznicy wyzwolenia obozu koncentracyjnego w Mauthausen stworzył Stimmen im Widerhall. Ein musikalischer Diskurs. Gulda jest też współzałożycielem i przewodniczącym stowarzyszenia RE.F.U.G.I.U.S. (Rechnitzer Flüchtlings- Und GedenkInitiative Und Stiftung), którego zadanie polega na upamiętnianiu ofiar zbrodni nazistowskich, zwłaszcza $\mathrm{z}$ terenów Burgenlandu, oraz tych, którzy pracowali przy budowie południowo-wschodniego wału obronnego (Südostwall ${ }^{18}$ ), a także

${ }^{16}$ D.R.L. Litchfield: Reason For Rechnitz Silence Revealed. Dostępne w Internecie: http:// www.davidrllitchfield.com/tag/elfriede-jelinek-research-centre/ [data dostępu: 24.07.2019].

${ }_{17}$ Tak pisze o Rechnitz Martin Pollack w książce Topografia pamięci (Przeł. K. NiedenTHAL. Wołowiec 2017, s. 90).

${ }^{18}$ Zespół fortyfikacji obronnych osłaniający południowo-wschodnią granicę Rzeszy przed nadciągającą Armią Czerwoną. Przy jego budowie pracowali m.in. członkowie Hitlerjugend, ludność cywilna, Ostarbeiter (robotnicy przymusowi ze Wschodu) oraz węgierscy Żydzi. Budowę rozpoczęto w październiku 1944 r. Do samego Rechnitz jesienią 1944 r. „sprowadzono robotników dwunastu narodowości: Francuzów, Greków, uchodźców z krajów bałkańskich, robotników 
uświadamianiu oddziaływania przeszłości na teraźniejszość. Na stronie internetowej stowarzyszenia napisano: „,...] uważamy za niezaprzeczalne, że z wydarzeń tamtych lat wynika dzisiaj szczególne zobowiązanie dla Austrii: poza upamiętnianiem stajemy $\mathrm{w}$ obronie humanitarnej, sprawiedliwej polityki uchodźczej i azylowej”19. Na stronie Gedenkweg, powiązanej z RE.F.U.G.I.U.S., znajdują się między innymi dwa szlaki pamięci prowadzące przez Rechnitz ${ }^{20}$ i Oberwart oraz poświęcony ponad stu zamordowanym romskim mieszkańcom gminy Kemeten ${ }^{21}$ wirtualny pomnik ${ }^{22}$, składający się z czerwonej litery „K”, która jest początkiem nazwy gminy, a także wyrażeń „Kein Ort der Trauer”, „Kein Ort des Gedenkens”, „Keine Ruhe” („żadnego miejsca żałoby”, „żadnego miejsca pamięci”, „żadnego spokoju"). Jest to, jak podaje opis na stronie, również znak przeciwko zapomnieniu i zamilczeniu na śmierć („gegen das Vergessen und Totschweigen”).

Pierwsze poszukiwania grobów przeprowadzano na obszarze sąsiadującym z Kreuzstadl - dawnym budynkiem rolniczym posiadłości Batthyánych zbudowanym na planie krzyża (stąd nazwa), którego ruiny pełnią obecnie funkcję pomnika upamiętniającego ofiary masakry w Rechnitz. W pierwszą środę marca 2019 roku zostały podjęte kolejne starania o zlokalizowanie masowego grobu zamordowanych - według stowarzyszenia RE.F.U.G.I.U.S. to już szesnasta próba odnalezienia ofiar tej krwawej nocy. Tym razem jednak rozszerzono przekopy-

przymusowych z terenów wschodnich, Muzułmanów z Serbii i Żydów z różnych państw [...]" (E. Schwarzmayer, Ch. Teuschler: Der Bau des Südostwalls und der Mord an ungarisch-jüdischen Zwangsarbeitern in Rechnitz. In: Die Mühen der Erinnerung. Zeitgeschichtliche Aufklärung gegen den Gedächtnisschwund. Wien 2002, s. 92-107). Jeśli nie zaznaczono inaczej, tłumaczenia cytatów obcojęzycznych - K.S.

19 „Andererseits halten wir es für unbestreitbar, dass sich aus dem Geschehen dieser Jahre eine besondere Verpflichtung für Österreich heute ergibt: über das Gedenken hinaus treten wir für eine humane, gerechte Flüchtlings- und Asylpolitik ein" (http://www.refugius.at/ [data dostępu: 24.07.2019]).

${ }^{20} \mathrm{Na}$ stronie Gedenkweg znajduje się także artykuł zamieszczony w „Oberwarther Sonntags-Zeitung" 20 marca 1938 r. (s. 2), relacjonujący entuzjastyczne przyjęcie w Rechnitz Anschlussu. Słowa o "tym radosnym historycznym przełomie w życiu naszego narodu” (http://www.ge denkweg.at/nationalsozalismus\#vorzeichen [data dostępu: 24.07.2019]), którego powszechnie wyczekiwano, oraz o muzyce towarzyszącej świętującym na ulicach ludziom nie dają o sobie zapomnieć, gdy myśli się o tytułowej formule książki Moniki Muskały. W połowie marca 1938 r., zaraz po przejęciu władzy przez miejscowych narodowych socjalistów, rozpoczęła się deportacja Żydów, miesiąc później została rozwiązana wspólnota religijna Rechnitz. Budynki, będące jej własnością, w tym synagoga i dawna szkoła żydowska, zostały skonfiskowane przez gestapo i zniszczone lub przeznaczone do pełnienia innych funkcji.

${ }^{21}$ Zob. rozdział zatytułowany Nie dla tablicy dla Romów. O pamięci i milczeniu w Burgenlandzie w Topografii pamięci... M. Pollacka.

${ }^{22}$ http://www.gedenkweg.at/gedenkort-kemeten/gedenkort-kemeten [data dostępu: 24.07.2019]. Stworzenie miejsca pamięci w takiej formie okazało się konieczne, gdyż większość decydentów politycznych gminy Kemeten wielokrotnie odrzucała pomysł utworzenia realnej formy upamiętnienia pomimo wsparcia ludności w tych dążeniach. Po 12 latach starań, jesienią 2018 r. powstała tablica, której daleko jednak do choćby przyzwoitej formy upamiętnienia ofiar. 
wany teren do leśnego obszaru na południe od Rechnitz, na które to miejsce wskazywał dziadek jednego z mieszkańców Burgenlandu, celnik, nazywając je „Judenwaldl”, i tam też będą kontynuowane prace poszukiwawcze jesienią lub wiosną przyszłego roku ${ }^{23}$. Te bezskuteczne próby odnalezienia ofiar oraz zdjęcia przekopywanych terenów pobrzmiewają słowami z dramatu Elfriede Jelinek i wiersza Paula Celana, a dla polskiego czytelnika także wersami utworu Czesława Miłosza. W kontekście środowiskowej historii Zagłady i zwłaszcza po zmianie obszaru poszukiwań masowego grobu na teren leśny każą również zastanowić się nad granicami, których przekroczenie grozi zniszczeniem także tych nie-ludzkich śladów pamięci ${ }^{24}$.

Pierwszym tekstem kultury - mającym cechy dokumentu - który opowiadał o tragicznej nocy w Rechnitz, czternaście lat przed Elfriede Jelinek, był film Margarety Heinrich i Eduarda Erne Totschweigen (1994, angielski tytuł to Wall of Silence). Wspomina o nim Jelinek w rozmowie z Moniką Muskałą, która pyta o bliskość, nie tylko geograficzną, Rechnitz i Oberwart:

Korzenie sięgają bardzo głęboko. W filmie Totschweigen [Na śmierć zamilczane], który poprzedził sztukę, jeden z mieszkańców mówi: bo to jest pogranicze, my jesteśmy pograniczem (przeciwko Węgrom, przeciwko Słowianom). To sugeruje, że granic trzeba bronić przed Innym. Niestety UE nie umiała z tym zrobić porządku, wręcz przeciwnie, napływ uchodźców wydaje się znacznie przyczyniać do pogłębiającej się izolacji. We wspomnianej okolicy jest więcej miejscowości, w których w ostatnich dniach wojny, gdy już wiadomo było, że wszystko stracone, popełniono podobne zbrodnie jak w Rechnitz. Wspomnę tylko masakrę w Deutsch Schützen.

s. 315

Jelinek i Muskała jedynie dotykają tu tematu, który chciałoby się, żeby wybrzmiał wyraźniej w książce o takim tytule. Jego ważność opisuje w swoich pracach między innymi Walter Manoschek ${ }^{25}$, zauważając, że przypadek Rech-

${ }^{23}$ „Kurier” 06.03, 07.03, 13.03.2019: https://kurier.at/chronik/burgenland/juedisches-massen grab-in-rechnitz-details-zur-suche-am-nachmittag/400427378; https://kurier.at/chronik/burgen land/rechnitz-grabungen-bringen-kein-ergebnis-aber-suche-geht-weiter/400427669; https://kurier. at/chronik/burgenland/erfolglose-grabung-wie-die-suche-nach-dem-massengrab-weitergeht/ 400434673.

${ }^{24}$ Zob. artykuł Romy Sendy KI: Nie-miejsca pamięci i ich nie-ludzkie pomniki. „Teksty Drugie" 2017, nr 2, s. 86-108. Autorka rozpoczyna swój tekst od przywołania pierwszych kadrów z filmu Totschweigen (o którym wspominam w dalszej części), pisząc, że „Rechnitz otacza dziś czarna legenda: mimo wysiłków (powojennych procesów, prób ekshumacji w latach 70. i pięcioletniego śledztwa autorów Totschweigen) zmowa milczenia (jak można by przetłumaczyć tytuł) i ogromna roślinna kurtyna ukrywają lokalizację grobu" (s. 87). Zob. też inne artykuły z tego numeru "Tekstów Drugich”, poświęconego w całości środowiskowej historii Zagłady.

${ }^{25}$ Profesor nauk politycznych Uniwersytetu Wiedeńskiego; jego badania koncentrują się na narodowym socjalizmie, studiach nad Zagładą oraz polityce pamięci. W 2009 r., wraz ze swoimi 
nitz nie był w Austrii w końcowych etapach wojny wyjątkowym ekscesem, lecz stanowił element serii tzw. Endphaseverbrechen ${ }^{26}$, „przestępstw fazy końcowej”, do których dochodziło wiosną 1945 roku.

W słowie będącym tytułem filmu Ernego i Heinrich (dla której był to ostatni projekt - kilka tygodni po premierze dokumentu odebrała sobie życie) zawarte jest zamilczanie na śmierć, ale też uśmiercanie przez milczenie. Gdyby zaś o austriackich rozliczeniach mówić w kontekście języka, można by umiejscowić je gdzieś na osi, na której leżą Totschweigen właśnie i Auslöschung (wymazywanie) $\mathrm{z}$ całą jego wieloznacznością. W krótkim eseju zamieszczonym po wywiadzie z Jelinek, a przed dramatem Rechnitz, Monika Muskała pisze:

studentami, opublikował pracę zbiorową Der Fall Rechnitz... Manoschek to m.in. współtwórca (w latach 1995-1999) przełomowej wystawy „Vernichtungskrieg. Verbrechen der Wehrmacht 1941-1944". Jest również redaktorem obszernego tomu Opfer der NS-Militärjustiz. Urteilspraxis Strafvollzug - Entschädigungspolitik in Österreich (Wien 2003) poświęconego ofiarom nazistowskiego wojskowego wymiaru sprawiedliwości, w tym dezerterom. Jego badania mają często szerokie oddziaływanie społeczne - w przypadku wspomnianego tomu, który powstał w ramach projektu badawczego Manoscheka i grupy młodych naukowców, były to czynności prawne (w 2009 r. Rada Narodowa przyjęła ustawę o uchyleniu wyroków nazistowskiego wojskowego wymiaru sprawiedliwości oraz rehabilitacji prawnej), a także powstanie w 2014 r. pomnika ofiar, mającego formę leżącego znaku X - dostrzec ją można jednak dopiero po wejściu na rzeźbę, podobnie jak znajdujący się na górnej warstwie wiersz konkretny Iana Hamiltona Finlaya, który składa się ze słów „all” i jednego „alone” na przecięciu linii tworzących X. Pomnik ten usytuowany jest w Wiedniu na Ballhausplatz, naprzeciwko budynku Kancelarii Federalnej oraz placu Bohaterów wraz z pałacem Hofburg (zob. http://www.deserteursdenkmal.at/) - pisze o nim w swojej książce Muskała, nie wspominając jednak o Manoscheku (s. 28). W 2012 r. ukazał się jego film dokumentalny pt. Dann bin Ich ja ein Mörder (doceniony m.in. przez Elfriede Jelinek), a trzy lata później książka (Dann bin Ich ja ein Mörder! Adolf Storms und das Massaker an Juden in Deutsch Schützen. Göttingen 2015) o pokrewnym Rechnitz morderstwie około 60 żydowskich robotników przymusowych z Węgier w Deutsch Schützen-Eisenberg. Manoschek był także uczestnikiem konferencji pt. „Niemieckie nazistowskie obozy koncentracyjne. Nowe projekty i wyzwania badawcze w Polsce i Austrii", która odbyła się w dniach 26-27 września 2016 r. w Stacji Naukowej Polskiej Akademii Nauk w Wiedniu, i wraz z Thomasem Pawłowskim przedstawił referat Społeczność getta. Strategie przetrwania austriackich Żydów w gettach dystryktu lubelskiego i radomskiego w Generalnym Gubernatorstwie 1941-1945, będący częścią większego projektu dotyczącego losów ponad 12000 austriackich Żydów deportowanych w 1941 i 1942 r. do sześciu gett w Generalnym Gubernatorstwie, zanim większość z nich zginęła w komorach gazowych podczas akcji „Reinhardt”. Informacje biograficzne o Manoscheku pochodzą ze strony Uniwersytetu Wiedeńskiego: https://staatswissenschaft.univie.ac.at/ team/wissenschaftliches-personal/walter-manoschek/ [data dostępu: 24.07.2019].

${ }^{26}$ Termin ten dotyczy zbrodni nazistowskich popełnianych w Niemczech i Austrii w okresie pomiędzy styczniem 1945 roku a lokalnymi datami końca działań wojennych. W wydawnictwie Justiz und NS-Verbrechen („Sprawiedliwość i zbrodnie nazistowskie”), zbierającym wydarzenia, które stały się przedmiotem procesów przed sądami RFN, przedstawiono 410 wyroków dotyczących przestępstw fazy końcowej. Robotnicy przymusowi stanowili znaczącą część ofiar, na których skupiona była przemoc ostatnich tygodni wojny na terenach Niemiec i Austrii. Warto byłoby przyjrzeć się zbrodniom nazywanym w badaniach niemieckojęzycznych Endphaseverbrechen w kontekście praktyk określanych jako Judenjagd i akcji „Reinhardt” w ostatniej fazie wojny na terenach Polski. 
Twórcom dokumentu Totschweigen [Na śmierć zamilczane] udało się na początku lat dziewięćdziesiątych dotrzeć do wielu świadków, którzy pamiętali tamtą noc. W całej wsi słychać było krzyki mordowanych i strzały - powiedzieli - słychać było je nawet przez zamknięte okna. Ale na pytanie, gdzie dokładnie zamordowano więźniów i gdzie są groby, nie chcieli już odpowiedzieć. Twierdzili, że nie wiedzą, nie pamiętają. „Rozgadane przemilczanie to austriacki fenomen” - mówi reżyser filmu Eduard Erne. Ktoś w jego dokumencie powie: „Żydzi mają Ścianę Płaczu, my mamy Ścianę Milczenia”.

Można żałować jedynie sygnalizującego - choć nadal wyrazistego - przywołania tego filmu przez autorkę, a przecież nawet przy zachowaniu tych skrótów myślowych oraz - być może celowych - niedopowiedzeniach książka jest obszerna i w niektórych momentach niezwykle szczegółowa.

Po raz pierwszy w Polsce sztukę Rechnitz (Anioł Zagłady) wystawiono w 2009 roku, w reżyserii Jossiego Wielera, na łódzkim Festiwalu Dialogu Czterech Kultur ${ }^{27}$. Spektakl szwajcarskiego reżysera miał premierę w Münchner Kammerspiele pod koniec 2008 roku. W swojej recenzji Monika Wasilewska, pisząc o „zagadywaniu” zbrodni, „mówieniu, które jest milczeniem” i „które niczego nie wyjaśnia”, wspomina, że „Wyświetlacz z tłumaczeniem nie nadąża ze zmianami”, ponieważ posłańcy ${ }^{28}$ „Mówią i mówią, prawie przez cały czas. Ale tak, żeby nic nie powiedzieć. Brodzą w gęstwinie skojarzeń, aluzji, interpretacji, odczuć, komentarzy [...]"29. Już wtedy napisy z kwestiami aktorów przełożyła Monika Muskała. Tak w rozmowie dla ZAiKS-u wspomina tłumaczka swoje pierwsze spotkanie z Rechnitz:

Z Rechnitz to był dziwny przypadek. Nie przepadam za Jelinek, nie wszystko mi się podoba, cenię ją, ale nigdy nie ciągnęło mnie, by przełożyć cokolwiek. A tu pamiętam, że przeczytałam w samolocie recenzję z prapremiery Rechnitz w Monachium i pomyślałam od razu: „Ja to chcę tłumaczyć!”. Pierwszy raz mi się zdarzyło, że bez czytania tekstu pomyślałam o przekładzie. Tak się złożyło, że Agata Siwiak wkrótce zaprosiła to przedstawienie na Festiwal Czterech Kultur w Łodzi i poprosiła mnie o przetłumaczenie napisów do wyświetlania. To było zaledwie 30 stron - cały tekst ma około 160. Jossie Wieler zrobił

${ }^{27}$ W tym samym roku inscenizacja ta została wyróżniona Nagrodą Nestroya.

${ }^{28}$ Agnieszka Łaszczuk w artykule poświęconym dramatowi Jelinek pisze o zastąpieniu przez austriacką pisarkę „kluczowej dla pisarstwa powojennego figury świadka postacią posłańca” oraz o związanej z tą postacią metodzie rekonstrukcji historii Georges’a Didi-Hubermana opartej na wyobraźni (A. ŁaszczuK: Nieskończone odkrywanie ukrytego: „Rechnitz (Anioł Zagłady)” Elfriede Jelinek. W: Pongo. T. 8: Ukryte w kulturze. Red. R. Cнумкоwsкi, A. Koprowicz. Katowice-Warszawa 2017, s. 226).

${ }^{29}$ M. Wasilewska: Anioł zagłady: Niemcy znów sa pępkiem świata. „Gazeta Wyborcza” z 20 stycznia 2010 r. Dostępne w Internecie: http://lodz.wyborcza.pl/lodz/1,35136,7474091,Aniol_ zaglady_Niemcy_znow_sa_pepkiem_swiata.html [data dostępu: 24.07.2019]. 
adaptację, bo tekst Jelinek jest monolityczny, bez podziału na role, wiadomo tylko, że mówią posłańcy, ale ustalenie, ilu ich jest i jakiej są płci należy do reżysera. [...] Nad tym przekładem spędziłam kilka lat - z przerwami. To chyba najtrudniejszy tekst, jaki kiedykolwiek tłumaczyłam ${ }^{30}$.

23 stycznia 2017 roku w Nowym Teatrze w Warszawie odbyła się otwarta próba (czytanie) Rechnitz (Anioł Zagłady) w reżyserii Katarzyny Kalwat, 25 września 2018 roku, podczas 61. Międzynarodowego Festiwalu Muzyki Współczesnej „Warszawska Jesień”, premierę miała wersja performatywna opery (Rechnitz. Opera - Anioł Zagłady; TR Warszawa), a premiera wersji teatralnej (poszerzonej o partie tekstu dotyczące współczesności oraz partie operowe dla Hrabiny) odbyła się 7 i 8 lutego 2019 roku (również w TR Warszawa) ${ }^{31}$. Osiem lat po inscenizacji Jossiego Wielera słowa utworu Jelinek wybrzmiewają już po polsku, nie muszą więc gonić za nimi napisy z tłumaczeniem, tym razem jednak tekstowi towarzyszy muzyka. Kompozytor opery Wojciech Blecharz mówił:

Operowość RECHNITZ. OPERY zawiera się przede wszystkim w nowym podejściu do formy recytatywu: poszukiwaniu ścisłych związków między tekstem a jego muzycznością, wydobywaniu z samego tekstu ukrytych znaczeń poprzez nakładanie na niego dźwiękowych gestów, przypisanych motywów, umuzycznienie jego prozodii czy rytmizację tekstu wypowiadanego przez aktora. Aktor staje się muzykiem, śpiewakiem, beatboxerem, jego sposób podawania tekstu sprzężony jest organicznie z zespołem czterech wiolonczel, które śledzą narrację, akompaniują aktorom, ale ich partie mają też wymiar performatywny. Kwartet wiolonczel symbolizuje to, co ostało się z pałacowej orkiestry z czasów dawnej świetności - ostatnich niedobitków, zmuszonych zabawiać swoją grą zdegenerowaną arystokrację oraz towarzyszących jej nazistów podczas krwawych wydarzeń z marca 1945 roku $^{32}$.

Katarzyna Kalwat zwraca też uwagę na drugą funkcję muzyki w spektaklu, czyli „zagłuszanie, rozpuszczanie sensów i znaczeń w tej historii, która opowiada

30 „Bez formy rzeczywistość jest amebą”...

${ }^{31} 8$ lutego, po spektaklu, odbyła się też dyskusja „Słowa na wojnie. Język i przemoc we współczesnej debacie publicznej”. Tłem był nie tylko tekst sztuki Jelinek, swoisty esej o języku (jak mówi o nim też Kalwat) dotyczący procesu przemilczania i zakłamywania nazistowskich zbrodni w powojennej Austrii, ale także aktualna polska rzeczywistość społeczno-polityczna (i funkcjonowanie w niej języka), m.in. zamach na prezydenta Gdańska Pawła Adamowicza, do którego doszło niespełna miesiąc wcześniej. O roli literatury austriackiej w Polsce zob. Samokrytyka z importu. Rozmowa z A. Lederem, A. Lipszycem, B. Stasińską, A. PeŁkĄ, J. Sową. „Dwutygodnik.com” 2017, nr 210. Dostępne w Internecie: https://www.dwutygodnik.com/artykul/7165-samokrytykaz-importu.html [data dostępu: 24.07.2019] (tekst stanowi zapis dyskusji „Samokrytyka z importu. Po co Polakom Jelinek, Bernhard i inni gniewni Austriacy?”, która odbyła się w październiku 2016 r. w Austriackim Forum Kultury w Warszawie).

${ }^{32}$ http://www.warszawska-jesien.art.pl/wj2018/program-i-bilety-2018/utwory/1099206784 [data dostępu: 24.07.2019]. 
o tym, jak język staje się narzędziem manipulacji [...], zmienia narrację, zakłamuje historię"33. Poza tymi znaczeniami polifonia recytatywu ${ }^{34}$ i muzyki odsyła także do makabrycznego absurdu okoliczności, w jakich doszło do zbrodni w Rechnitz - „zakotwicza nas w tej historii na zamku” ${ }^{35}$, mówi Kalwat.

Temat Rechnitz powracał w ciągu ostatnich lat kilkukrotnie - w różnych formach, zwłaszcza literackich, i zdaje się też, że powodowany rożnymi motywacjami. Dramat Jelinek ${ }^{36}$ pochodzi z roku 2008, ale rok wcześniej we „Frankfurter Allgemeine Zeitung" ukazał się mówiący o tej tragicznej nocy 1945 roku artykuł zatytułowany Die Gastgeberin der Hölle („Gospodyni piekła”) brytyjskiego dziennikarza i autora monografii rodu Thyssenów Davida R.L. Litchfielda, który wielokrotnie ostro sprzeciwiał się temu, w jaki sposób i w jakich okolicznościach mówi się o Rechnitz ${ }^{37}$. Z kolei w 2016 roku nakładem Residenz Verlag ukazała się Topografia pamięci (Topografie der Erinnerung) Martina Pollacka, w tym samym roku wydana została także książka Sachy Batthyany'ego, potomka potężnego rodu arystokratycznego, krewnego hrabiny, zatytułowana Und was hat

${ }^{33}$ Blecharz: o zbrodni w Rechnitz nie da się opowiedzieć słowami. Audycja radiowa Poranek Dwójki z 4 lutego 2019 r. Prowadził J. Kukla, goście: K. Kalwat (reżyserka) i W. Blecharz (kompozytor). Warszawa, Polskie Radio Program Drugi. Dostępne w Internecie: https://www. polskieradio.pl/8/404/Artykul/2257293,Blecharz-o-zbrodni-w-Rechnitz-nie-da-sie-opowiedziecslowami [data dostępu: 24.07.2019].

${ }^{34}$ Forma recytatywu pozwala zachować potok słów, w tym także interseksualność utworu Jelinek, wielość kryptocytatów i cytatów. O nawiązaniach literackich (do Bachantek Eurypidesa, Zamku Franza Kafki, poezji Paula Celana, Tako rzecze Zaratustra Friedricha Nietzschego, a przede wszystkim do poematu Próżni ludzie Thomasa Stearnsa Eliota, którego liczne frazy Jelinek wplata do swojego tekstu) oraz odwołaniu się, już w podtytule dramatu, do filmu Luisa Buñuela Anioł Zagłady pisze w swojej recenzji Adam Lipszyc (Czarne języki. „Literatura na Świecie” 2017, nr 7-8, s. 401-413).

${ }^{35}$ Blecharz: o zbrodni w Rechnitz nie da się opowiedzieć słowami...

${ }^{36} \mathrm{Na}$ temat utworu E. Jelinek zob. „Die endlose Unschuldigkeit“. Elfriede Jelineks „Rechnitz (Der Würgeengel)“. Hrsg. P. Janke, T. Kovacs, Ch. Schenkermayr. Wien 2010.

${ }^{37}$ Krytykował m.in. książkę Sachy Batthyany’ego, która swój początek ma właśnie we wspomnianym artykule Litchfielda. Batthyany pisze: „Przed ukazaniem się w prasie artykułu o Rechnitz i ciotce Margit dzieje mojej rodziny mało mnie interesowały. Zresztą nie miałem właściwie okazji, żeby się z nimi zetknąć. Gdybym się urodził na Węgrzech, wyglądałoby to zupełnie inaczej - bo tam co krok trafiałbym na miejsca i gmachy upamiętniające moich przodków. Dzieciństwo spędziłem jednak nie w Budapeszcie, ale w czteropokojowym mieszkaniu na przedmieściu Zurychu" (S. Batthyany: A co ja mam z tym wspólnego? Zbrodnia popetniona w marcu 1945. Dzieje mojej rodziny. Przeł. E. Bielicka. Warszawa 2017, s. 14). Litchfield zarzuca autorowi między innymi brak źródeł informacji, jakie podaje w swojej książce, oprócz pamiętnika jednej z żydowskich ofiar jego rodziny oraz dziennika babki Maritty, który w tajemniczy sposób planuje zniszczyć po tym, gdy ujawnił ich, zredagowaną przez siebie, treść. Krytykuje zaprzeczanie wielu dowodom, poglądy Batthyany'ego na temat komunizmu, a także przekonanie o tym, że jego ciotka na pewno sama nie strzelała do Żydów (D.R.L. Litchfield: An Admission of the Batthyany-Thyssens' Guilt - Served through a Revolving Door. Dostępne w Internecie: http://www. davidrllitchfield.com/2016/04/an-admission-of-the-batthyany-thyssens-guilt-served-through-arevolving-door/ [data dostępu: 24.07.2019]). 
das mit mir zu tun? Ein Verbrechen im März 1945. Die Geschichte meiner Familie (A co ja mam $z$ tym wspólnego? Zbrodnia popetniona w marcu 1945. Dzieje mojej rodziny ${ }^{38}$.

Jelinek pisze przede wszystkim o językowym obchodzeniu się z przeszłością, o pułapkach, w jakie wpadają słowa podczas debat historycznych, w komentarzach społeczno-politycznych, ale też w codziennym mówieniu o przeszłości. W spektaklu Katarzyny Kalwat ${ }^{39}$ teatralne doświadczanie rozgadania i muzyki, połączone z treścią zdań w różnych rejestrach językowych, nawiązuje do tragicznego absurdu sytuacji, w jakiej odgłosy pozornie niewinnego (gdyby nie nazwy stopni wojskowych przed nazwiskami gości hrabiny Margit) i kulturalnego (gdyby nie ekscesy związane $\mathrm{z}$ wykorzystywaniem dla przyjemności kobiet pracujących na zamku) przyjęcia mieszają się z krzykami mordowanych, zabijaniem dla rozrywki. Książka Sachy Batthyany’ego zdaje się przede wszystkim próbą uspokojenia własnego sumienia i odrobieniem prywatnej lekcji historii, a tym samym rozrachunkiem $\mathrm{z}$ wieloletnim milczeniem członków rodziny autora. Pozostaje jednak wrażenie, że dziennikarz nie wykorzystuje szansy powiedzenia o Rechnitz tego, co mógłby powiedzieć, gdyby nie koncentrował się na podkreślaniu ciężaru bycia potomkiem sprawców. Martin Pollack z kolei włącza Rechnitz do podróży po miejscach, które naznaczone są śmiercią i przemilczaniem. W Topografii pamięci najcenniejsze okazują się jednak te fragmenty, gdzie autor mierzy się z haniebną przeszłością swojej rodziny. Integralną część tekstu - podobnie jak w książce Moniki Muskały - stanowią fotografie, w tym przypadku pochodzące z archiwum autora, ale Pollack często współpracuje także z Chrisem Niedenthalem, jednym $\mathrm{z}$ najbardziej cenionych współczesnych europejskich fotoreporterów. Te dwie, tak przecież różniące się od siebie publikacje (choćby $\mathrm{z}$ tego powodu, że warsztat reporterski i literacki Martina Pollacka jest nieporównywalnie bogatszy niż Batthyany’ego), powiązane z tomem Muskały historią

${ }^{38}$ S. Batthyany: A co ja mam $z$ tym wspólnego?... Tytuł ten tłumaczony jest odmiennie w różnych językach, inaczej kładąc punkt ciężkości pytania: przekład francuski, podobnie jak polski, podkreśla cząstkę ,ja”: Mais en quoi suis-je donc concerné? Un crime en mars 1945. L'histoire d'une grande famille hongroise (Trad. N. CHRISTOPHER. Paris 2017); najbliżej oryginału pozostają tłumaczenia na języki duński, czeski i rumuński, a w przekładzie angielskim książka zatytułowana jest A Crime in the Family. A World War II Secret Buried in Silence - and My Search for the Truth (Transl. A. Bell. London 2017) - podobnie brzmi to w tłumaczeniu na norweski. Przekład angielski nie korzysta z popularnego wyrażenia „What's that got to do with the...?” („Co to ma wspólnego z...?”), oznaczającego nieadekwatność do danego tematu, non sequitur. W książce tytułowe sformułowanie pojawia się jako pytanie niemieckiego pisarza Maxima Billera skierowane do Batthyany'ego - „A co to ma z tobą wspólnego?”; w formie, która przyjęta jest w polskim tytule tomu, zdanie to pojawia się wewnątrz narracji, choć nie istnieje w takim brzmieniu w oryginale („Co ja tu właściwie robię? Co ja mam z tym wszystkim wspólnego?” $i$ „Was tat ich hier eigentlich? Was hatte ich hier verloren?”).

${ }^{39}$ Więcej na temat Rechnitz. Opera - Anioł Zagłady pisał np. J. KIsIELIŃsKi w recenzji pt. Rechnitz: roztańczona otchłań. Dostępne w Internecie: http://www.austriart.pl/2019/03/rech nitz-roztanczona-otchlan-rechnitz-aniol-zaglady-recenzja/ [data dostępu: 24.07.2019]. 
Rechnitz, stanowią przedłużenie podjętego przez nią tematu, mówiąc o austriackich, także tych prywatnych, rodzinnych, rozliczeniach.

Wobec - nadal obecnej - luki w powszechnej świadomości różnicy pomiędzy wojennymi historiami Niemiec i Austrii oraz form rozliczania się z przeszłością przez oba te państwa ważne jest istnienie książki w sposób przystępny omawiającej te tematy oraz atrakcyjnej również pod względem edytorskim i graficznym. Sylwiczna kompozycja tego tomu umożliwia czytanie i oglądanie go na różne sposoby, a dzięki temu jego wielokrotnie ponawianą obecność. Można czytać go linearnie, zgodnie z linią, którą wyznacza autorka (od części reportażowej po tekst utworu Jelinek), od końca, można go kartkować, oglądać, wracać do wybranych stron. Warto przy tym podkreślić, że wiedza o okolicznościach Anschlussu oraz zbiorowym zapominaniu i usprawiedliwianiu, pozbawiona ram naukowego studium o winie austriackiej, nie pozostaje bez znaczenia także dla polskich rozmów o niewygodnych, przykrywanych rozdziałach historii. Publikacja Muskały ma szansę sprawdzić się też - choćby wybiórczo - na licealnych lekcjach historii ${ }^{40}$, wiedzy o społeczeństwie czy języka polskiego, tym bardziej że w ostatnich latach znacząco zwiększyła się liczba przekładów utworów niemieckojęzycznych, które związane są z tematami podejmowanymi przez Muskałę i obecnymi w humanistycznej edukacji licealnej.

Jest to więc książka interdyscyplinarnie ważna i potrzebna. Mówiąca innym głosem (innymi głosami ${ }^{41}$ ) i mająca inne grono odbiorców niż nieliczne, wcześniejsze teksty podejmujące podobne tematy ${ }^{42}$. Wyróżniona została wieloma nagrodami: Górnośląską Nagrodą Literacką „Juliusz”, przyznaną przez „Literaturę na Świecie” Nagrodą im. Andrzeja Siemka („za łączenie różnych kompetencji literackich i literaturoznawczych, przekładu i pisarstwa krytycznego wysokiej próby"43), została też nominowana do Nagrody Literackiej Nike oraz Nagrody Literackiej GDYNIA. W 2019 roku autorka Między „Placem Bohaterów”

${ }^{40} \mathrm{Na}$ lekcjach historii np. przy okazji omawiania drogi Hitlera do władzy, charakterystyki Trzeciej Rzeszy z uwzględnieniem przebiegu Anschlussu, przedstawiania etapów Zagłady Żydów (szczególnie fazy końcowej), na lekcjach wiedzy o społeczeństwie (będącej z założenia przedmiotem interdyscyplinarnym) m.in. podczas dyskusji o podziałach w społeczeństwie na "swoich” i „obcych”, różnych formach ksenofobii i dyskryminacji oraz języku nienawiści, na lekcjach polskiego natomiast kontekstowo przy omawianiu np. Wizyty starszej pani Friedricha Dürrenmatta (lektura uzupełniająca zakresu podstawowego), twórczości Witolda Gombrowicza (fragmenty Ferdydurke jako lektura obowiązkowa zakresu podstawowego), Procesu Franza Kafki (fragmenty - lektura obowiązkowa zakresu rozszerzonego) (informacje zawarte w podstawie programowej dla liceum i technikum, obowiązującej od 2018 r.: https://podstawaprogramowa.pl/).

${ }^{41}$ Muskała zamieszcza w swojej książce rozmowy z sześcioma ważnymi dla kultury austriackiej oraz rozliczeń z przeszłością osobami: Gerhardem Rothem (kilkukrotnie), Hermannem Beilem, Peterem Turrinim, Helmutem Schödelem, Urlichem Seidlem i Elfriede Jelinek.

${ }^{42}$ Przede wszystkim książka Karola Franczaka Kalający własne gniazdo. Artyści i obrachunek z przeszłością, wydana w 2013 r. (Kraków).

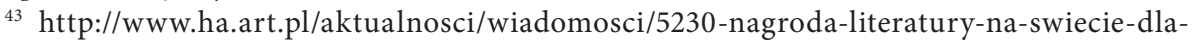
ksiazki-moniki-muskaly.html [data dostępu: 24.07.2019]. 
$a$ „Rechnitz”... została również laureatką Nagrody im. Karla Dedeciusa przyznawanej przez Fundację Roberta Boscha i Niemiecki Instytut Spraw Polskich w Darmstadt (Deutsches Polen-Institut) za wybitne osiągnięcia translatorskie oraz wkład na rzecz porozumienia polsko-niemieckiego.

\section{Bibliografia}

Batthyany S.: A co ja mam z tym wspólnego? Zbrodnia popetniona w marcu 1945. Dzieje mojej rodziny. Przeł. E. Bielicka. Warszawa 2017.

Bernhard, czyli My i oni. Rozmawiają M. Muska£A, K. Lupa, J. Margański. „Didaskalia” 2016, nr 131, s. 34-39.

„Bez formy rzeczywistość jest amebą”. Z M. MuskaŁą rozmawiała J. BIERnACKA. „ZAiKS. TEATR" 2017, nr 12. Dostępne w Internecie: http://www.zaiksteatr.pl/rozmowaz. id_502,monika_muskala [data dostępu: 24.07.2019].

Blecharz: o zbrodni w Rechnitz nie da się opowiedzieć słowami. Audycja radiowa Poranek Dwójki z 4 lutego 2019 r. Prowadził J. Kukla, goście: K. Kalwat (reżyserka) i W. Blecharz (kompozytor). Warszawa, Polskie Radio Program Drugi. Dostępne w Internecie: https://www.polskieradio.pl/8/404/Artykul/2257293,Blecharz-o-zbrod ni-w-Rechnitz-nie-da-sie-opowiedziec-slowami [data dostępu: 24.07.2019].

Der Fall Rechnitz Das Massaker an Juden im März 1945. Mit einem Text von Elfriede Jelinek. Hrsg. W. Manoschek. Wien 2009.

„Die endlose Unschuldigkeit“. Elfriede Jelineks „Rechnitz (Der Würgeengel)“. Hrsg. P. Janke, T. Kovacs, Ch. Schenkermayr. Wien 2010.

DudziŃska K.: Od amnezji do amnestii? „Didaskalia” 2017, nr 139/140, s. 142-143.

Franczak K.: Kalający własne gniazdo. Artyści i obrachunek z przeszłościa. Kraków 2013.

Grzebia w języku, jakby grzebali w ziemi. Z M. MusKa£Ą rozmawiał M. RoBerT. „Tygiel Kultury" 2017, nr 2, s. 13-26.

Historikerstreit. Spór o miejsce III Rzeszy w historii Niemiec. [Red. M. Łukasiewicz]. Londyn 1990.

JelineK E.: Rechnitz (Anioł Zagłady) [fragmenty]. „Notatnik Teatralny” 2012/2013, nr 70/71, s. 316-320.

Kisıeliński J.: Rechnitz: roztańczona otchłań. Dostępne w Internecie: http://www. austriart.pl/2019/03/rechnitz-roztanczona-otchlan-rechnitz-aniol-zaglady-recenzja/ [data dostępu: 24.07.2019].

Kry LOVA K.: Genre and Memory in Margareta Heinrich's and Eduard Erne's Totschweigen and Elfriede Jelinek's "Rechnitz (Der Würgeengel)". In: Genre Trajectories. Identifying, Mapping, Projecting. Eds. G. DowD, N. Rulyova. Basingstoke 2015, s. 66-85.

LATKowsKa M.: Historikerstreit - przyczyny i skutki jednego z najważniejszych niemieckich sporów o historię w XX wieku. „Studia Interkulturowe Europy Środkowo-Wschodniej" 2012, T. 6, s. 4-24. 
Lipszyc A.: Czarne języki. „Literatura na Świecie” 2017, nr 7-8, s. 401-413.

LitchField D.R.L.: An Admission of the Batthyany-Thyssens' Guilt - Served through a Revolving Door. Dostępne w Internecie: http://www.davidrllitchfield.com/2016/04/ an-admission-of-the-batthyany-thyssens-guilt-served-through-a-revolving-door/ [data dostępu: 24.07.2019].

Litchfield D.R.L.: Reason For Rechnitz Silence Revealed. Dostępne w Internecie: http://www.davidrllitchfield.com/tag/elfriede-jelinek-research-centre/ [data dostępu: 24.07.2019].

Łaszczuk A.: Nieskończone odkrywanie ukrytego: „Rechnitz (Anioł Zagłady)” Elfriede Jelinek. W: Pongo. T. 8: Ukryte w kulturze. Red. R. Cнумкошsкi, A. Koprowicz. Katowice-Warszawa 2017, s. 215-226.

Manoscheк W.: Dann bin Ich ja ein Mörder! Adolf Storms und das Massaker an Juden in Deutsch Schützen. Göttingen 2015.

Materniak-Pawıowska M., Olszewski H.: Spory o narodowy socjalizm na łamach Poznańskiej Biblioteki Niemieckiej. „Czasopismo Prawno-Historyczne” 2014, T. 66, z. 1, s. 323-336.

Milczenie zawsze moge przerwać. Z S. Batthyany m rozmawiała M. KicıńsKa. Dostępne w Internecie: https://www.newsweek.pl/kultura/sacha-batthyany-o-nowej-ksiazce-itrudnych-losach-rodziny-wysiad/66zbmvt [data dostępu: 24.07.2019].

Mıєкоwsкi T.: Austria według Muskały. „Dziennik Trybuna” z 15-17 lutego 2019 r., s. 21.

MuskaŁa M.: Między „Placem Bohaterów” a „Rechnitz”. Austriackie rozliczenia. Kraków 2016.

Nazizm, Trzecia Rzesza a procesy modernizacji. Wybór i oprac. H. OrŁowski. Poznań 2000.

Noc, o której milczeliśmy. Z S. BAtThyAnym rozmawiała K. Brejwo. „Gazeta Wyborcza” z 25 października 2017 r., s. 14-15.

O kondycji Niemiec. Tożsamość niemiecka $w$ debatach intelektualistów po 1945 roku. Red. J. JaвŁкowska, L. Żyliński. Poznań 2008.

Oczyszczenia nie będzie. Austria (nie) rozlicza się z faszyzmu. Z M. MuskaŁą rozmawiała K. Brejwo. „Gazeta Wyborcza” z 17 lipca 2017 r., s. 12-13 [dodatek: „Duży Format"]. Dostępne w Internecie: http://wyborcza.pl/duzyformat/7,127290,22095935, austria-nie-rozlicza-sie-z-faszyzmu.html [data dostępu: 24.07.2019].

Opfer der NS-Militärjustiz. Urteilspraxis - Strafvollzug - Entschädigungspolitik in Österreich. [Hrsg. W. Manoschek]. Wien 2003.

OrŁowski H.: Nazizm, Trzecia Rzesza a procesy modernizacji. „Przegląd Zachodni” 1992, nr 4, s. 79-100.

Pawlicka K.: W piwnicy nie zawsze knebluje się usta. „Znak” 2017, nr 10, s. 110-111.

Pollack M.: Topografia pamięci. Przeł. K. Niedenthal. Wołowiec 2017.

Roвert M.: Rodzinna tajemnica. „Znak” 2018, nr 1, s. 112-113. Dostępne w Internecie: http://www.miesiecznik.znak.com.pl/rodzinna-tajemnica-a-co-ja-mam-z-tymwspolnego-batthyany/ [data dostępu: 24.07.2019].

SAdulski B.: Pamięci, przemów. „Magazyn O!Kultura” 2017, nr 23. Dostępne w Internecie: https://kultura.onet.pl/wiadomosci/pamieci-przemow-recenzja/ew8wvt6 [data dostępu: 24.07.2019]. 
SAdulski B.: Recenzja książki Sachy Batthyany'ego „A co ja mam z tym wspólnego?”. „Herito” 2017, nr 4, s. 176-177.

Samokrytyka $z$ importu. Rozmowa z A. Lederem, A. Lipszycem, B. Stasińską, A. PeŁkĄ, J. SowĄ. „Dwutygodnik.com” 2017, nr 210. Dostępne w Internecie: https://www.dwu tygodnik.com/artykul/7165-samokrytyka-z-importu.html [data dostępu: 24.07.2019].

Schwarzmayer E., Teuschler Ch.: Der Bau des Südostwalls und der Mord an ungarisch-jüdischen Zwangsarbeitern in Rechnitz. In: Die Mühen der Erinnerung. Zeitgeschichtliche Aufklärung gegen den Gedächtnisschwund. Wien 2002, s. 92-107.

Sendyka R.: Nie-miejsca pamięci i ich nie-ludzkie pomniki. „Teksty Drugie” 2017, nr 2, s. $86-108$.

Szczepaniak M.: Ludo-żercy dobro-czyńcy. Karl Kraus i Elfriede Jelinek. „Porównania” 2018, nr 1 (22), s. 219-236.

Teatr, który się wtraca. Rozmowa z Pawłem Łysakiem i Pawłem Sztarbowskim. „Dwutygodnik" 2014, nr 127. Dostępne w Internecie: https://www.dwutygodnik.com/ artykul/5059-teatr-ktory-sie-wtraca.html [data dostępu: 24.07.2019].

Wasilewska M.: Anioł zagłady: Niemcy znów sq pępkiem świata. „Gazeta Wyborcza” z 20 stycznia 2010 r. Dostępne w Internecie: http://lodz.wyborcza.pl/lodz/1,35 136,7474091,Aniol_zaglady__Niemcy_znow_sa_pepkiem_swiata.html [data dostępu: 24.07.2019].

Wittchen-Bare£kowska A.: Anatomia Austrii. „Teatr” 2017, nr 7-8, s. 128-129.

ŻER Ko S.: Ernst Nolte, główna postać niemieckiego „sporu historyków”. „Biuletyn Instytutu Zachodniego" 2016, nr 267. Dostępne w Internecie: https://iz.poznan.pl/plik, pobierz,1644,b76a1391a109ee1c17fa0e0f87d379ec/267Noltesporhistorykow.pdf [data dostępu: 24.07.2019].

Katarzyna Szymańska

Against Austria - the Postcard

On Monika Muskała’s Między „Placem Bohaterów” a „Rechnitz”

Austriackie rozliczenia

Summary

This article focuses on Monika Muskała’s Między „Placem Bohaterów” a „Rechnitz”. Austriackie rozliczenia [Between the Heroes Square and Rechnitz. Settling the Austrian Cases] with regard to Elfriede Jelinek's "Rechnitz (The Angel of Death)" included in it. Moreover, it shows how Jelinek's play has been adapted in Polish theatres and discusses other publications dedicated to the Rechnitz massacre of March 1945 (including Martin Pollack's and Sacha Batthyany's books). Various materials regarding Jewish people being forced to work in Burgenland and its territories are recalled in the article, which also calls for perceiving the Rechnitz as one of many crimes that took place in the last stage of World War II: not a unique case (this issue is tackled in Walter Manoschek's research), but the Endphaseverbrechen instead.

Key words: Austrian literature, Monika Muskała, Elfriede Jelinek, Rechnitz, National Socialism, Holocaust, politics of memory, Endphaseverbrechen 

Dokumenty 
